This item was submitted to Loughborough's Research Repository by the author.

Items in Figshare are protected by copyright, with all rights reserved, unless otherwise indicated.

\title{
Effective regulation for sustainable public transport in developing countries
}

PLEASE CITE THE PUBLISHED VERSION

PUBLISHER

(C) Elsevier

LICENCE

CC BY-NC-ND 4.0

\section{REPOSITORY RECORD}

Sohail, M., D.A.C. Maunder, and Sue Cavill. 2019. "Effective Regulation for Sustainable Public Transport in Developing Countries". figshare. https://hdl.handle.net/2134/3845. 
This item was submitted to Loughborough's Institutional Repository (https://dspace.lboro.ac.uk/) by the author and is made available under the following Creative Commons Licence conditions.

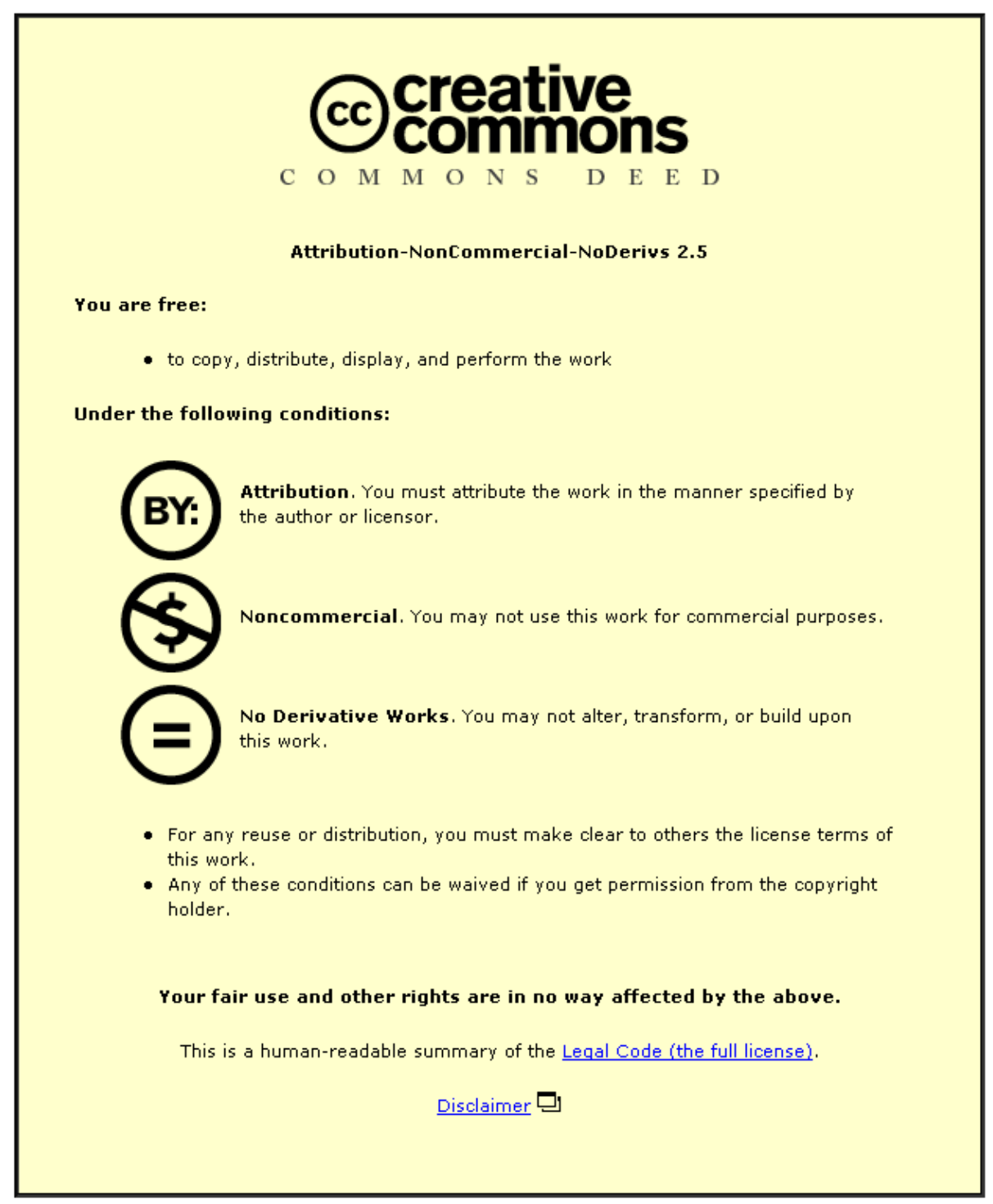

For the full text of this licence, please go to: http://creativecommons.org/licenses/by-nc-nd/2.5/ 
Effective Regulation for Sustainable Public Transport in Developing Countries M.Sohail ${ }^{1}$ D.A.C Maunder ${ }^{2}$ and S. Cavill ${ }^{3}$

1 Senior Research Manager, WEDC, Department of Civil and Building Engineering, Loughborough University, UK

${ }^{2}$ Independent Public Transport Consultant

${ }^{3}$ Research Scholar, WEDC, Department of Civil and Building Engineering, Loughborough University, UK 


\begin{abstract}
This paper has two key objectives. Firstly, using the findings from case study research undertaken in Colombo (Sri Lanka), Faisalabad (Pakistan) and Dar es Salaam (Tanzania), the paper seeks to demonstrate the importance of an appropriate regulatory framework and effective mechanisms of enforcement for sustainable urban transport systems in developing countries. Secondly, the paper highlights the critical importance of communication and co-ordination between stakeholders (defined here as transport users, providers and regulators) if regulation is to be effective. The views of poor and disadvantaged passenger groups-women, children, the elderly and disabled-are used in the paper to illustrate the importance of transport systems to their livelihoods, such as work, education, health and social pursuits. The case studies suggest that in the context of the failure of both the fully regulated public transport sector and the completely deregulated sector self regulation is a potentially useful alternative. In practice self regulation has been achieved in the case study locations through the formation of cooperatives or associations of stakeholders such as users and operators.
\end{abstract}

In the conclusion, the paper makes two key points. Firstly, that regulation must be open, honest and effective, but not so detailed or 'heavy' that it incites the potential for corrupt practices

Secondly, communication and co-ordination between stakeholders is critical if any form of regulation is to be effective-owners', employees' and passengers' associations have a vital role in this regard, as do Transport Forums consisting of all stakeholders. The participation of stakeholders and real and effective consultation are more important in the case of self regulation of public transport service provision than in other regulatory regimes.

\title{
Introduction
}

During the last two decades many cities throughout the world have seen a shift from publicly owned and managed surface public transport services to privately owned and operated systems. As a consequence, the issue of an appropriate form of regulation to manage, apparently, chaotic public transport provision needs to be revisited. This paper presents selected findings from a project undertaken in Colombo (Sri Lanka), Faisalabad (Pakistan) and Dar es Salaam (Tanzania) between 2001 and 2003 on behalf of the UK Department for International Development [DFID]. See Sohail, Mitlin and Maunder (2003) for the full report of the project.

These case study cities were chosen on the basis that they represent urban areas with a significant number of poor people. Additionally, they offered an array of different levels of private operation of public transport service provision, different levels of use of motorised transport and different cultural contexts thus enabling the authors to collect a rich data base for the research project. The differences include the availability of different modes of urban transport and differences in the proportion of people that have access to public transport services.

The primary objective of the project was to identify key stakeholders in each of the cities studied and to explore and map the key perspectives of customers of public transport who are typically excluded from the normal planning and implementation of transport policy. Consequently, to understand roles and responsibilities and analyse the working linkages and mechanisms used to deliver public transport services. General lessons or 
guidelines have been drawn from these case studies for use by policymakers and urban public transport operators (Sohail, Mitlin and Maunder, 2003) in order to secure the potential benefits public transport offers the urban poor throughout their livelihood activities.

\section{Purpose of the research}

Case studies were undertaken in Faisalabad (Pakistan) (Sohail, 2003a), Colombo (Sri Lanka) (Sohail, 2003b) and Dar es Salaam (Tanzania) (Sohail, 2003c) under a Knowledge And Research [KAR] project entitled 'Partnerships to Improve Access and Quality of Public Transport for the Urban Poor', funded by the DfID. The purpose of the research was to find out why the regulation of public transport provision in many developing countries appears to be ineffective and how to increase the efficiency and effectiveness of any form of regulation for a sustainable and accessible public transport system.

\section{Some basic definitions}

Before moving on to discuss the research findings, transportation and poverty, key terms used in this research, are defined below:

Transportation systems are intended to move people and goods to where they need to go-safely, quickly and affordably. Land based public transport modes include trains, buses and minibuses, but also taxis trams and trolleys, metros and 'para-transport' vehicles such as rickshaws, bicycles and motorcycle taxis. Improving the efficiency and effectiveness of any system depends on both infrastructure and modes. In the context of the project, public transport was defined as services comprising formal and informal modes (vehicles) where a fare is paid by a passenger.

Poverty can be understood in terms of lack of income, expenditure or consumption, but also refers to the capacity of people to meet their basic needs (water, shelter, food, health and education, access to labour markets) (Carney, 1998; Ashley, and Carney, 1999; DFID, 1999; Carney Drinkwater, Rusinow, Neefjes, Wanmali and Singh, 1999).

Urban public transport is a key link to access other services and livelihood assets. Access to affordable transport is critical for the urban poor as it offers a way out of economic, social and physical isolation. Accessibility to transport has a number of dimensions for example it might be physical i.e. the user has to travel a long distance to find public transport, or else public transport might be financially unaffordable or the mode of transport might have inadequate capacity. The typical transport issues raised by the urban poor relate to the availability, cost, quality and safety of public transport. Many respondents to this research also reported on environmental issues related to noise and air pollution. 


\section{Why regulation or de- regulation?}

The Public Interest Theory of regulation explains, in general terms, that regulation seeks the protection and benefit of the public at large. The usual aim of a regulatory regime in developed and developing countries is the common protection of customers' collective interests through the government-organized regulation of private companies ${ }^{4}$. Government has been involved in the transport market to protect customers and employees by introducing quality and safety standards, controlling the quantity of services as well as the price controls by regulating the entry of new transport operators. Regulation sets out the rules under which both service provider and regulator must operate. Historically, examples of such regulation in the transport sector include road service licenses, vehicle emission controls, speed limits, control of bus fares, procedures on vehicle inspections and maintenance, and controls on toll road private companies, privatized canals and railway companies. Regulation is intended to ensure that high standards are maintained through testing, monitoring and benchmarking transport provision. Regulatory effectiveness (irrespective of the sector) depends on the independence of the regulator in order to prevent regulators being 'captured' by those they are supposed to be regulating. Furthermore, the quasi-legal nature of regulation makes its processes open to scrutiny and challenge by all parties and constrains the regulator to act wholly within the capacity and authority given to him under the relevant legislation or contract provisions.

Regulation has the potential to operate to the public advantage, putting into practice the policies of government as efficiently and effectively as possible. However, in a public choice model the regulator is viewed as a self-interested utility-maximizer motivated by such factors as salary, power and patronage and as such represents only pro-regulatory political interests when making decisions. Other commentators (World Bank, 1986; Vasconcellos, 2001; Estache \& de Rus, 2000; Cervero, 2000) suggest that the regulator may instead be captured by the industry, e.g. regulator identifies with firms that it is responsible for regulating, which may distort decision making and protect the industry from competition. Regulation may also suffer X-inefficiency, resulting from problems of "morale" or "bureaucratic inertia" in the context of the public sector.

Those who argue for transport deregulation and privatisation conclude that the state should confine its role to setting minimal regulations to ensure fair competition and safe operation of transport services. Deregulation of public transport is intended to foster competition in service delivery for a certain route or encourage free competition between large numbers of independent operators on the route or network. Proponents argue that deregulation should lead to increased cost savings, reduced fares, reduced overall public expenditure, improved service levels, greater innovation (such as the use of mini and midi buses) and a greater responsiveness to the needs of passengers.

\footnotetext{
${ }^{4}$ to ensure comprehensive service provision to stop social and financial differences emerging between areas and people.
} 
However, the argument for retaining a degree of regulation in the provision of public transport is made on the basis that regulation is necessary as a broad legal and institutional effort to ensure the provision of safe vehicles and a network of services for all but especially the most vulnerable groups in society. For example, deregulation might result in frequent changes to bus services, reduced reliability, passenger confusion over changing services, poor connections, increased traffic congestion, poor driver behaviour on the road to win passengers (bus wars), and fare increases if subsidies are eliminatedthus disadvantaging the poor in society. The absence of regulatory intervention can lead to market failure through the abuse of monopoly power, which results in excessive profits, declining standards and other externalities. In short, deregulation can threaten the viability of transport services in marginal areas and restrict the accessibility of poor households to employment opportunities and social services.

In the context of many developing countries where regulation has proved ineffective and deregulation restricts the accessibility of poor households to public transport, self regulation of the sector has emerged as a promising alterative.

\section{Public transport regulation in developing countries.}

Internationally in the 1980 s deregulation and privatisation policies were applied to industries and utilities. In the context of developing countries these were often part of Economic Structural Adjustment Packages as a condition of aid from developed countries and international agencies. In this context, state or municipal ownership and operation of transport was viewed as inefficient, heavily subsidised, poorly managed, bureaucratic and unresponsive to the market (Armstrong-Wright, and Thiriez, 1987; World Bank, 1986; Estache \& de Rus, 2000). Accordingly, regulated transport industries in developing countries were deregulated or the regulatory regime was liberalised through a mixture of privatisation and commercialisation. The intention of deregulation was to introduce competition into the services, reduce public subsidies to public transport industries, shift transport operation from public to the private sector and improve resource allocation (World Bank, 1994). However, the results have been variable, for the reasons given above.

More recently, those concerned with the provision of public transport services in developing countries have shifted their concerns from transport infrastructure to the implications of transport provision to overcome poverty and inequality including the effects on improving health and well being, the environment, and people's access to employment and livelihoods (Sohail, 2000; Palmer, Astrop, \& Maunder, 1997). With respect to the urban poor, deregulation was intended to improve access by providing low cost methods of transport that are better able to respond to consumer needs and provide a variety of services with different qualities and fares (Vasconcellos, 2001; Barter, 1999; Bose and Nesamani, 2001; Cervero, 2000; Pedersen, 2000; Orn, 2002). 


\section{Why the research was undertaken}

In the context of developing countries, relationships between agencies and in some cases partnerships between agencies (both informal and formal) provide the poor with access to public transport services. However, there is a lack of understanding about how such partnerships function to deliver public transport services and what can be done to support them. This study addressed a number of key questions: firstly how existing partnerships can be strengthened and new ones established in respect of public transport provision? Secondly, how the views of users, operators and regulators can be integrated and how should priorities be established at the operational and policy levels? Thirdly, how the need of the urban poor for safe, affordable, effective and efficient public transport services can be understood, quantified and prioritized to ensure reasonable access to work, education, health and leisure when other factors (such as water, food, housing and health) are equally or more important for sustaining livelihoods?

In short how public transport provision in developing countries can be effectively regulated and sustained to serve the needs of all residents in society but especially vulnerable groups such as the poor, disabled, aged and the young 


\section{Methods and scope of enquiry}

The predominant 'how and why' nature of this research led to a case study approach. It was understood at the outset that case studies would not generate statistically representative generalizations; however, they would contribute to the logical explanation of events on the basis of both quantitative and qualitative data (see, for example, Yin, 1993). The study locations, Faisalabad (Pakistan), Colombo (Sri Lanka) and Dar es Salaam (Tanzania), provided a variability of situation and hence allowed a rigorous testing of the findings. Methodological considerations used in the planning of the research are presented in Appendix 1.

These case study locations were chosen on the basis that they represent urban areas with a significant number of poor people, different levels of private operators, different levels of use of motorised transport and different cultural contexts thus enabling the authors to collect a rich data base. The differences include the availability of different modes of urban transport services and differences in the proportion of people that have access to public transport services (see Tables 1, 2 and 3).

Table 1 Modal Split of Urban Public Transport in Colombo

\begin{tabular}{|c|c|c|c|c|c|c|}
\hline Area & \multicolumn{2}{|l|}{$\begin{array}{l}\text { Estimated vehicle ownership } \\
\text { (per 1000 people) }\end{array}$} & \multicolumn{5}{|l|}{ Ownership level by vehicle type } \\
\hline & & Motorcycle & $\begin{array}{c}3- \\
\text { wheeler }\end{array}$ & $\begin{array}{c}\text { Car and } \\
\text { van }\end{array}$ & Freight & Buses \\
\hline CMC & 262 & $\begin{array}{c}66 \\
(25 \%)\end{array}$ & $\begin{array}{c}31 \\
(12 \%)\end{array}$ & $\begin{array}{c}113 \\
(43 \%)\end{array}$ & $\begin{array}{c}45 \\
(17 \%)\end{array}$ & $\begin{array}{c}8 \\
(3 \%)\end{array}$ \\
\hline & & & & & & \\
\hline
\end{tabular}

Source Colombo Urban Transport Study - stage 2 undertaken by W/S Atkins International UK

Table 2 Modal Split of Urban Public Transport in Faisalabad

\begin{tabular}{|l|l|l|l|}
\hline Type of vehicle & $\begin{array}{l}\text { Total number of } \\
\text { vehicles }\end{array}$ & $\begin{array}{l}\text { Ratio with respect to } \\
\text { households }\end{array}$ & $\begin{array}{l}\text { Ratio with respect to } \\
\text { persons }\end{array}$ \\
\hline Car & 29,390 & $\begin{array}{l}1 \quad \text { car per } 9.7 \\
\text { households }\end{array}$ & car per 74 persons \\
\hline Motorcycle & 138,366 & $\begin{array}{l}1 \text { motorcycle per } 2 \\
\text { households }\end{array}$ & $\begin{array}{l}1 \text { motorcycle per 15 } \\
\text { persons }\end{array}$ \\
\hline Bicycle & 238,188 & $\begin{array}{l}1 \text { bicycle per } 1.2 \\
\text { households bicycle per } 9 \\
\text { persons }\end{array}$ \\
\hline Other vehicle & 2,632 & $\begin{array}{l}1 \text { other vehicle per } \\
108 \text { households }\end{array}$ & $\begin{array}{l}1 \text { other vehicle per } \\
829 \text { persons }\end{array}$ \\
\hline
\end{tabular}

Source the above table is based on the 1996 study named Traffic Study in Faisalabad. The number of vehicles is calculated proportionately based on current population.

Table 3 Modal Split of Urban Public Transport in Dar Es Salaam

\begin{tabular}{|l|l|l|l|l|l|}
\hline Type of vehicle & $\%$ & 1965 & 1968 & 1979 & 1982 \\
\hline Car & $\%$ & 66.9 & 67.8 & 52 & 25.4 \\
\hline Motorcycle & $\%$ & 2.2 & 3.5 & 6 & 7.3 \\
\hline Bicycle & $\%$ & 2.2 & 3.5 & 16 & 7.3 \\
\hline Other vehicle & $\%$ & 17.7 & 20.2 & 26 & 60 \\
\hline Total & 100 & 100 & 100 & 100 \\
\hline
\end{tabular}

Source NTC A Review of Urban Public Transport in Dar Es Salaam 1965-1982 (1989; 36). 
The case studies examined the impact of the provision of public transport, in terms of price, affordability, access and quality, and the ability of the poor to sustain and improve their livelihoods and economic status. A general finding of this research is that the lack of an effective regulatory framework is in itself a failure of both policy and practice and a key factor in the lack of an efficient and effective public transport system. It will be concluded that a regulatory regime that encompasses both formal and informal transport providers is a key element when attempting to improve sustainable public transport services in developing countries.

Both quantitative and qualitative research techniques were used to establish the views of transport users (including men, women, children and the elderly and disabled members of the community), operators and regulators. Research techniques included content analysis, such as a travel diary, literature reviews, historical analysis, case studies, focus group discussions, forums and workshops. Approximately 300 interviews with key informants were conducted. Focus groups and workshops were used to explore such issues as pedestrian access to services, fares, reliability of services, how new routes/services are planned and how local community views can be included in defining transport services. Fifteen forums, three city-level workshops and one international workshop were held. In addition, several sources of secondary data, including unpublished reports, were reviewed during the course of the study. Table 4 provides basic information on estimated population and national rates of urban growth in the case study locations.

Table 4 Estimated population and national rate of urban growth

\begin{tabular}{|l|c|c|c|l|c|}
\hline & $\begin{array}{l}\text { City population } \\
\text { (est. 2000) }\end{array}$ & $\begin{array}{l}\text { Rate of urban growth } \\
1990-5\end{array}$ & $\begin{array}{l}\text { Rate of urban } \\
\text { growth 1996-2000 }\end{array}$ & $\begin{array}{l}\text { \% of national } \\
\text { population } \\
\text { below national } \\
\text { poverty line }\end{array}$ & $\begin{array}{l}\text { National } \\
\text { GDP per head } \\
\text { (US\$) }\end{array}$ \\
\hline Dar es Salaam & $2,347,000$ & 8.33 & 6.31 & $\begin{array}{l}36 \% \text { (2002 } \\
\text { est.) }\end{array}$ & 700 \\
\hline Colombo & 642,020 & 0.45 & 0.46 & $\begin{array}{l}22 \% \text { (1997 } \\
\text { est.) }\end{array}$ & 4,000 \\
\hline Faisalabad & $2,232,000$ & 4.14 & 4.31 & $\begin{array}{l}32 \% \text { (FY00/01 } \\
\text { est.) }\end{array}$ & 2200 \\
\hline
\end{tabular}

Source: United Nations (2001), World Urbanization Prospects: the 1999 Revision, United Nations (Population Division), New York; Census of Colombo population 2001; City of Colombo Development Plan - Urban Development Authority 1996.CIA The World Fact Book.

[For additional background information on the case study cities please see the summary in Table 6. 


\section{General Regulatory issues}

The three case studies yielded a variety of findings. However, the common factor in all three study locations is that a public sector monopoly has been replaced by private sector provision of public transport services.

In general, cost and customer pressures for increased frequency and flexibility have led private operators worldwide [including in the case study cities] to rely upon a large number of small capacity vehicles. These small scale private transport service vehicles are demand responsive, flexible and better able to offer services in low income areas but are frequently associated with high waiting times [at certain times of the operational day], fare irregularities, excessive overcrowding, the operation of unsafe and ill maintained vehicles and at peak periods there is often discrimination against school children and pensioners carried at concessionary fares. Alternatively, public sector firms [where still operational] typically operate large capacity buses in search of presumed economies of scale (Urban Resource Centre, 2001)

The challenge is, therefore, to find a way to regulate and control this multiplicity of small businesses [often one operator will own and operate only one vehicle] in such a way as to retain the cost-minimization pressures of the profit-seeking private sector without sacrificing safety, health or quality of service. For example, public transport might operate in a framework that is regulated by government or self regulated through transport operator cooperatives or route associations. The efficiency and performance of public sector transport services might be judged in terms of the increased use of services by passengers, reduced fares, improved service levels (increased frequency of service, a faster service, greater reliability, improved service penetration to outlying residential areas, and greater flexibility of service provision), improved passenger information, disabled access, protection of concessionary fares, vehicle quality control (safety and fitness of vehicles), easy interchanges and responsive to customers needs. 


\section{The regulatory systems in the case study locations}

In all three cities, minibuses or shared taxis are the most common modes of public transport. These vehicles tend to be owned in small fleets; so ownership is widespread and as a result are difficult to regulate and control. Devolution of power has occurred frequently over the last decade or so, with the central government implementing policies at the national level and city or municipal authorities attempting to regulate and control public transport at the local level (with varying degrees of success).

While cities have expanded in population and area, the public transport fleet has generally not kept pace with this growth; hence at peak times vehicles tend to be overcrowded (sometimes dangerously so). Operators prefer busy high passenger demand routes so as to maximize earnings, and this is a factor that contributes to congestion on such routes along with infrastructure capacity limitations, enforcement constraints, funding limitations etc. Other areas and routes within the overall system tend to be neglected, resulting in an uneven and infrequent service provision.

The regulatory system of the country case studies is described below and summarised in table 6.

\section{Dar es Salaam:}

The traffic department of the Police Force is responsible for designating and allocating routes to public bus operators, whereas the DRTLA (Dar es Salaam Regional Transport Licensing Authority) is inter alia responsible for monitoring and enforcing route compliance among operators. Currently, it is estimated that there are 6,000 -7,500 privately owned vehicles, of which only 6,000 are properly registered and licensed, and there only 20-30 owned by the public sector. A permit for a route is normally valid for one year and costs TShs.200, 000. This excludes unofficial 'incentive payments', which certain respondents suggested may be imposed by officers involved in the permit and or route allocation process. The Police Force is also involved in inspecting vehicles for their roadworthiness and testing of drivers for professional competency to drive various categories of vehicles.

Although the City authorities are working to develop such a policy at the present time, the regulatory institutions are largely ineffective and there are no procedures for assessing customer service levels or providing a forum where stakeholders can propose improvements.

\section{Faisalabad}

Regional Transport Authorities (RTAs) were established under Section 46 of the Motor Vehicle Ordinance (1965) with power to issue route permits, issue bodybuilding licenses, check overloading, issue licenses to goods forwarding agencies and impose penalties on violators. In 1982 an independent office of the RTA was established for the Faisalabad Division. With the introduction of the District Government Plan in 2000, the administrative set-up was amended and the RTA is now responsible for the Faisalabad District. It has 
started planning to reduce traffic congestion at important junctions, especially during rush hours, and has suggested the following measures to improve the system:

- provide effective training courses for users, operators and regulators;

- eliminate corruption;

- construction of good quality roads; and

- reduce encroachment from the city, particularly the Central Business District, to improve transport flow.

The office of the Motor Vehicle Examiner reports directly to the Secretary of the RTA and operates under the powers of Motor Vehicle Rules. Its main functions are to issue and renew fitness certificates to all modes of motorised public transport and impose penalties on those found guilty of running unfit public transport vehicles.

\section{Sri Lanka:}

A number of agencies do exist in Sri Lanka to guide and regulate public transport services. however due to a lack of proper coordination at national as well as city level, these agencies fail to properly address the problems relating to public transport and to provide a quality service to the public. The large number of individually operated private bus services make it difficult to control and monitor their activities. There is a view that the lack of strong political commitment to regularize the operation of private bus services is due to pressure from influential bus operators. Reckless driving by private bus drivers is an additional problem, due partly to poor law enforcement. There are also complaints that government owned buses are restricted to inherently unprofitable routes, while the most profitable routes are left to private operators. This situation has led to a general withdrawal of services from some routes so that some passengers are left without any form of public transport service available.

Regulatory agency personnel emphasize the need for all parties to cooperate in implementing traffic rules and regulations. It was observed that there is no significant partnership arrangements in operation in the sector. The intended partnership between the Ceylon Transport Board and private bus operators proved to be unrealistic. Other transport modes such as school vans, three-wheelers and office staff transport vans, are operated mostly on an individual basis with no effective partnership arrangements between users, transport operators and regulators. Most poor areas are not directly linked to the main roads, and local roads are in a very poor condition.

Table 5 Similarities and differences in regulation found in the case studies

\begin{tabular}{|l|l|}
\hline $\begin{array}{l}\text { Similarities between case } \\
\text { studies }\end{array}$ & Differences in case studies \\
\hline $\begin{array}{l}\text { Minibuses or shared taxis } \\
\text { are the most common modes } \\
\text { of public transport. }\end{array}$ & $\begin{array}{l}\text { In Colombo, central } \\
\text { formation on private } \\
\text { companies with a minimum } \\
\text { requirement of } 50 \text { vehicles to }\end{array}$ \\
\hline
\end{tabular}




\begin{tabular}{|c|c|}
\hline & $\begin{array}{l}\text { be operated within a specific } \\
\text { area }\end{array}$ \\
\hline $\begin{array}{l}\text { A lack of co-ordination } \\
\text { between the private and } \\
\text { public sectors at national as } \\
\text { well as city level for the } \\
\text { allocation of routes and time } \\
\text { schedules, poor road } \\
\text { conditions, untrained crews } \\
\text { and revenue leakage are the } \\
\text { main problems. }\end{array}$ & $\begin{array}{l}\text { In Faisalabad Regional } \\
\text { Transport Authorities (RTAs) } \\
\text { regulate the sector. } \\
\text { Although, FUTS model has } \\
\text { proved successful both from } \\
\text { a regulatory and a planning } \\
\text { perspective, as both city } \\
\text { transport administrators and } \\
\text { passengers benefit from a } \\
\text { more regular and reliable } \\
\text { service }\end{array}$ \\
\hline $\begin{array}{l}\text { Agencies fail to properly } \\
\text { address the problems } \\
\text { relating to public transport } \\
\text { and to provide a quality } \\
\text { service to the public. }\end{array}$ & $\begin{array}{l}\text { In Dar es Salaam traffic } \\
\text { department of the Police } \\
\text { Force take the lead in } \\
\text { regulation. }\end{array}$ \\
\hline $\begin{array}{l}\text { No procedures for assessing } \\
\text { customer service levels or } \\
\text { providing a forum where } \\
\text { stakeholders could propose } \\
\text { improvements. }\end{array}$ & \\
\hline
\end{tabular}

\section{Regulation and control}

Regulation can be applied in three ways- in respect of:

- Quality,

- Quantity and

- Price or fare.

The findings from the case study cities indicate that effective urban public transport regulation requires a clearly defined framework to guide governments, municipalities, and other stakeholders. Although such a framework needs to be developed within the specific local public transport context, there are a number of general issues or guidelines that such a framework needs to consider. These are discussed below with reference to the case study locations:

Quality control in the bus industry mainly concerns the construction, maintenance and operation of vehicles. Such regulation is justified by the difficulty faced by consumers in assessing whether or not the vehicle they are boarding is safe, and by the advantage in 
applying common minimum standards. Quality control may also necessitate setting up complaints mechanisms. For example women who participated in the focus groups for this research and/or who were interviewed during the case studies stated that 'Passengers do not know where to complain when they face a problem while travelling on a bus'. Furthermore, respondents typically said that 'There is no passenger association or any other known civil society organization where passengers can make a complaint'. Another said that 'We are not aware of our rights as passengers of public transport.' However, if standards are specified in excessive detail, it is possible that useful innovations will be stifled and operations will become steadily less efficient and economical. In addition, from a quality and safety standpoint, it would be helpful if regulators made more efforts to encourage owners to provide better conditions and security of employment for their drivers and conductors.

Quantity control limiting the number of vehicles that may operate on a particular route, can combat congestion and bring about a more efficient use of resources. However, such control can also be anti-competitive and, by offering preference to a limited number of operators, it also offers potential advantages to those with undue or improper influence. For example, respondents claimed that some school buses are only available for certain recognized schools. The children of poor settlements who attend less prominent schools do not have a school bus service. These children have to use ordinary passenger buses, which is difficult for them especially when paying reduced fares during peak hours as operators frequently refuse to carry them unless made to by the police or other adult passengers.

Price or fare control can be useful in avoiding excessive tariffs, particularly where quantity control limits competition. However, 'fair' tariffs are difficult to set, and there is again a danger of corruption if the regulator enjoys excessive powers. Moreover, transport providers can avoid such controls. For example, they will not transport low paying passengers (such as the discounted fare scheme for students in Dar es Salaam) and /or they break their journey arbitrarily to ensure a double payment. As many respondents stated 'We are not aware of our rights as passengers of public transport.' Thus regulation should be applied only to meet well-considered and generally agreed objectives. Outcomes in the transport sector can also be influenced by sector structure, which is in part influenced by the government. For example, routes may be given to a single operator, or to several operators. It may be necessary to consider incentives such as well-designed, simple, transitional and targeted subsidies in order to encourage operators to serve poorer areas. The criteria for subsidies should be carefully defined, for example whether better value is obtained by subsidizing bus services or by instead providing direct assistance to the urban poor? In addition, should services that operate in poor areas be subsidized in general, so that all passengers benefit, or should specific categories of passengers be targeted so that, for example, those on low incomes, the disabled, school children and the elderly benefit?

In all three cities, the case study authors concluded that there was 'poor co-ordination of the public transport sector', and considerable difficulties in controlling the private operators in terms of routes and timetables. To some extent, this is inevitable in a market in which route profitability is highly variable and entry is often loosely regulated, because 
existing operators are forced to be competitive in order to avoid losing market share to newcomers. However, there is a need for sufficient order within the sector so as to offer a reliable and predictable service to passengers. The case study authors reported that even if a vehicle had been assigned a particular route to operate, it was extremely difficult to ensure that the vehicle only operated on that route unless some form of operators' association enforced the rule on behalf of its members. The police authorities appeared not to be able to enforce the current route system or chose not to do so.

Regulation is necessary to ensure that owners:

- are of good personal repute;

- possess adequate managerial and technical skills;

- have sufficient financial resources;

- have facilities for proper vehicle maintenance; and

- do not demand excessive working hours from their employees.

Besides these problems in the regulation and control of public transport services, there are also constraints on planning and co-ordinating services in the three cities.

In Sri Lanka, the former Ceylon Transport Board has been restructured to function as eleven separate Regional Transport Companies (RTCs), sharing the assets and responsibilities of the regional bus companies amongst its employees and the state. The relatively lower efficiency of the public sector bus transport service ensures that the private sector services 66 per cent of all passenger kilometres travelled in the city. In order to simplify regulation, control and planning, in the year 2000 the central government encouraged the formation of private companies with a minimum requirement of 50 vehicles to be operated within a specific area. By the end of that year there were ten such companies (or co-operatives) registered and operational. Although this will not by itself solve the complex problems of public transport provision in the capital, it should enable better planning of the network to occur between the private and public sectors. It may also generate pressure to improve transport infrastructure. In its 2000 Annual Report, the Central Bank of Sri Lanka stated that:

'the private bus operators, though they provide a greater part of the service, are still faced with a number of problems which need to be resolved if they are to improve the standards of their services. Nonavailability of bus stations and parking spaces, a lack of co-ordination between the private and public sectors for the allocation of routes and time schedules, poor road conditions, untrained crews and revenue leakage are the main problems.'

In Faisalabad, an interesting scheme (operational since 1994) has tried to overcome the limitations of public sector operations and to capitalize on the potential of the private sector. The government encouraged the establishment of a non-governmental organization entitled the Faisalabad Urban Transport Society (FUTS), which is supported by government administrative facilities and management. The FUTS operates as a co- 
operative that: manages and runs urban transport services using private transport operators; maintains transport facilities within the city limits; and facilitates the replacement of old and obsolete vehicles with newer, more environmentally friendly models. It operates on 14 routes and has over 1,000 vehicles operating daily (mainly small minibuses). Being a social welfare agency, it has social obligations to its members and has a social outlook in respect of its transport operations. For instance, it ensures routes are not 'cut' by its drivers (a frequent temptation for private operators), by establishing checkpoints along the routes. The FUTS model has proved successful both from a regulatory and a planning perspective, as both city transport administrators and passengers benefit from a more regular and reliable service. Although the operation has been less successful recently, the FUTS shows that there are interventions into urban public transport that can benefit passengers.

The public sector company UDA in Dar es Salaam is in virtual decline due to the total monopoly by the private sector. However, its existence is now being reconsidered under new public transport plans for the city.

\section{Infrastructure}

In addition to reviewing the modes of transport available in the case study locations, public transport infrastructure facilities were found by users to be inadequate in all three cities. Transport users raised issues related to the importance of developing better regulatory regime and implementation mechanisms in relation to:

- traffic management measures

- pedestrian walkways

- driver behaviour and discipline

- Weatherproof bus stands/ stops

These issues are discussed in turn below and illustrated with examples of the views of women, children and elderly passengers who participated in the focus groups and/or who were interviewed during the case studies.

During peak hours, public transport vehicles are not provided with any priority over other motorized vehicles. Thus, minibuses frequently queue with other traffic seeking to enter or leave the city. Pedestrians have similarly low priority: 'even on the pedestrian crossings, drivers, motorcyclists and three-wheeler drivers do not slow down their vehicles ... Normally we have to wait at the pedestrian crossing for five to ten minutes until the road is clear to cross over to the other side.' Public transport vehicle productivity and efficiency could be substantially improved if simple, relatively low-cost traffic management measures were introduced, such as lane priority, priority at traffic signals, bus-only corridors and lay-bys to service passengers. In reality, however, such measures need to be enforceable.

Respondents thought that transport infrastructure and modes must give consideration to pedestrians. For example, one respondent said that 'some pedestrian walkways are not properly constructed and children sometimes fall and get hurt.' One child said that 'Most pavements are narrow, hence I cannot catch hold of my mother's arm and walk with her along the pavement.' Furthermore, 'during the rainy season, it is difficult to use the 
access roads in our settlement. Roads become waterlogged and full of muddy holes.' Respondents complained that pavements are encroached upon by businessmen, vendors and parked vehicles; 'we cannot use the pavements. We cannot walk with our children either, because the pavements are too narrow and crowded'. In particular, female respondents said that 'It is dangerous for women to walk at night along the inner access roads to the settlement... Thieves often break the streetlights to make the road dark at night... Thieves snatch our bags and jewellery. They also harass young girls. Sometimes men attempt to rape girls.'

Good driver behaviour and discipline are essential if these measures are to provide benefits for public transport vehicles. Elderly respondents said 'We do not go out of our homes except for an essential purpose because now the roads are too dangerous for us to walk. Even when we do go out, we have to seek the help of our children or someone else'. Others said that 'We walk along the pavements very carefully because we are scared of reckless drivers overtaking another vehicle, three-wheelers, potholes and uneven surfaces. Cars, vans and three-wheelers park on the pavements so we have to walk on the road, which is really dangerous'. Similarly school children reported that when they cross the road using pedestrian crossings, drivers do not normally give way. Female respondents stated that 'Pedestrian travel is a real problem for us because the threewheeler drivers and young boys make offensive jokes. Sometimes they purposely turn their vehicles towards us to get our attention.' Children complained that 'When bus drivers speed and race one another, and when they suddenly apply the brakes, we get thrown about since we cannot hold the handrail because it is too high.' In addition it was stated that 'bus drivers sometimes fail to stop the bus at the bus stop; instead they take us further from the bus stop, which is inconvenient to us.'

Weatherproof bus stands/ stops are needed along the routes, and waiting bays should be provided for vehicles at bus stations or terminals along with comfortable facilities for passengers. Elderly respondents to this research typically stated 'We can't stand and wait for a long time for a bus, so we need a place to sit. But there are no proper bus shelters. (...) Bus shelters do not provide any traveller information (...) are often occupied by beggars and drug addicts, and are made dirty [and] (...) do not seem to be maintained by anyone'. Where services are operated to a schedule, timetables should be provided to inform passengers of the service frequency. Respondents also pointed out that 'Road names are not properly displayed on the streets and we sometimes get lost as a result. Proper name boards on roads are necessary.' Others noted that school children throw wastepaper and wrappings on the road or at the bus stops, since there are no waste bins provided.

\section{Guidelines on regulation}

Historically, governments in the case study cities sought to provide public transport services through a monopoly public sector supplier, which they owned and controlled and which often did not have operational and financial objectives as key performance criteria. Unfortunately many of these suppliers had poor performance, were subject to undue 
political influence and were unwilling or unable to react appropriately to changing customer demands hence the rise of the private operators.

However, the case studies also provide evidence of the problems that can arise with privately owned and operated services due to a lack of regulation and regulatory capacity. Deregulation of the public transport sector in these countries, has led to an increase in the number of individual operators (minibus or shared taxi services), whose main aim is to maximise profits. Unfavourable driver behaviour was found to adversely affect passenger safety and comfort and damage the urban environment. For example, vehicles 'racing' each other to stops along the route to either pick up passengers or complete their trip to pick up more passengers for the return journey. It was noted that vehicles were worked hard with little preventative maintenance, so breakdowns en route became a frequent occurrence. Operators (drivers and conductors) typically hired their vehicles on a daily payment basis, having to guarantee the owner an agreed sum. The result was that the vehicles were worked as long as possible to maximise earnings for the operators.

However, some form of regulation is deemed necessary to protect the interests of the poor. For example, in the case study cities low income communities are frequently located on the outskirts of cities with poor and narrow road access to the main urban road network. Such narrow roads are more accessible to minibus type operators than to large conventional buses. However, owners and operators generally preferred to keep to the major road networks to safeguard their vehicles. So the urban poor often face long walks on poorly maintained pavements and poorly illuminated streets to reach any type of service. Dark alleys were reported as places where women were frequently harassed. A long journey in a vehicle in often cramped conditions will follow, before another journey on foot to reach their destinations.

Where public transport services are provided by large numbers of small private operators, the sector is inevitably characterized by competition and fragmented ownership. One possible strategy to prevent some of these potential problems arising is through self regulation of the public transport sector, as demonstrated in the FUTS example in the Faisalabad case. As discussed above, the Faisalabad Urban Transport Society (FUTS) is effectively a public-private partnership that acts to regulate quality, quantity and price in public transport. The example of FUTS suggests that it is possible to find a middle ground, restricting access to routes but being somewhat flexible. Clearly there is an incentive for excess supply on some routes, but such conditions are not in the interest of either users or the industry.

The case studies also revealed the importance of dialogue between key actors in order to resolve critical issues in the public transport service sector. Consultation with stakeholders (operators, administrators of public transport, users, and regulators) can also ensure self -regulation by ensuring that the opinions, problems, wishes and issues of the community (as users) and the operators (as suppliers) of transport are taken into account in the transport planning and development process. Participation also enables inclusiveness to be developed, giving a voice to the poor, disabled, women and other 
disadvantaged groups. Besides addressing direct problems with the provision of public transport services, a Transport Forum can also discuss other transport needs and requirements such as: pedestrian facilities for both the able-bodied and disabled; the maintenance of pavements and roads; and traffic management measures to segregate motorized and non-motorized traffic. However, at the present time there does not appear to be such a channel of communication in any of the cities studied. In Colombo, it was reported that:

'... there is a lack of appropriate outlets for making complaints and enquiries about public transport services. Passengers are unable to channel their complaints to the right authorities for the necessary actions to be taken, and operators and regulators are unable to get information on passenger needs and demands. Thus services and facilities provided are based on operators' whims'.

Similarly, the Dar es Salaam report suggests:

'... overall, the present civil society is not playing any significant role in the public transport sector. There is therefore an urgent need to establish a forum for discussion whereby bus owners, operators and users would meet to discuss pertinent problems on public transport so as to improve the quality of public transport service to the users.'

However, the research on which this paper is based did bring such meetings of all stakeholders together in all three cities for the first time. These Transport Forums were successful and effective and indeed are still meeting today.

WE HAVE SHOWN THAT SELF REGULATION WORKS IN THE FUTS SYSTEM BUT NOT IN DAR OR COLOMBO DO WE NEED TO MAKE MORE OF IT ? TO REINFORCE THE CONCLUSIONS? 


\section{Conclusions}

The role of transport regulators is crucial. Regulators must ensure that the supply of public transport services is of sufficient quantity and quality [in terms of safety] to meet the perceived demand, and that the service is provided at an affordable price. This paper set out to demonstrate the need and importance of an appropriate regulatory framework and effective mechanisms of enforcement for sustainable urban transport systems in developing countries using the findings from case study research undertaken in Colombo (Sri Lanka), Faisalabad (Pakistan) and Dar es Salaam (Tanzania).

Nevertheless, the overriding concern in all three cities was the lack of effective regulation of privately owned and operated public sector services. Where public transport services are provided by large numbers of small private operators, the sector is inevitably characterized by competition and fragmented ownership. However, the case studies show that transport owners' and employees' associations and cooperative can play an important role in developing sustainable public transport in developing countries through self-regulation.

This paper also sought to highlight the critical importance of communication and coordination between stakeholders (defined here as transport users, providers and regulators) if regulation is to be effective. The forums developed through the research project proved successful in the case studies as a mechanism to improve communication between different groups of stakeholders (users, operators, and regulators). These forums were used to address policy and strategic issues as well as highlighting more immediate concerns. For instance, in ensuring the interests of pedestrians are taken into account in respect of the provision and maintenance of pavements or that services are provided as near to a residential area as is operationally possible. Another example is where streets are narrow and poorly maintained, it was suggested that some kind of 'feeder' service might need to be developed to provide connections with public transport routes, as has been the case with auto-rickshaws or chincha (motorcycle taxis) in the case study locations. In the future forums of transport stakeholders could consider lowcost traffic management measures, including bus priority, segregation of motorized and non-motorized vehicles, parking, traffic signals and pedestrian-only areas.

Overall, consumers of public transport services in the study locations were found to be suffering from a sense of helplessness. Respondents believed their voices were not being heard in service delivery and in many cases people did not know the first enquiry point in making a comment or complaint. In some instances, resorting to violence was perceived to be the only way to register a protest. However, burning of buses, injuries to passengers and drivers, and the loss of valuable assets can be avoided with the provision of properly regulated public transport services. Thus, whatever the regulatory regime it should include mechanisms for listening to the voices of all stakeholders including vulnerable groups if they are to improve the quality of life and sustain the development of the city and its residents in the future. 


\section{References}

1. Armstrong-Wright, A. and Thiriez, S (1987) Bus Services Reducing costs, Raising standards. World Bank Technical Paper Number 68, Urban Transport Series, World Bank: Washington D.C.

2. Ashley, C. and Carney, D. (1999) Sustainable livelihoods: Lessons from early experience. Department for International Development: London, UK.

3. Barter, P. A. (1999) Transport and urban poverty in Asia: a brief introduction to the key issues Regional development dialogue / United Nations Centre for Regional Development, 20,no.1: 143-63

4. Bose, R. K., Nesamani, K.S. (2001) Issues, strategies, and challenges for sustainable urban transport: modelling the impact on the local and global environment - the case of Delhi Pacific and Asian journal of energy, 11,no.1, 31-49

5. Carney D., M. Drinkwater, T. Rusinow, K. Neefjes, S. Wanmali and N. Singh (1999) Livelihoods approaches compared. Department for International Development: London, UK.

6. Carney, D. (Ed.) (1998) Sustainable rural livelihoods: What contribution can we make? Department for International Development: London, UK.

7. Cervero, R. (2000) Informal transport in the developing world United Nations. Centre for Human Settlements (Habitat) Nairobi: UNCHS.

8. Department for international Development (1999) Sustainable livelihoods guidance sheets. DFID: London, UK.

9. Estache, A., de Rus, G.U (2000) Privatization and regulation of transport infrastructure: guidelines for policymakers and regulators World Bank Institute Washington D. C.: The World Bank.

10. Orn, H. (2002) Urban traffic and transport Housing Development and Management vol. 12, no. 2. Swedish International Development Cooperation Agency Building issues ; Lund: HDM

11. Palmer, C., A. Astrop, and, D.A.C., Maunder (1997) Constraints, attitudes and travel behaviour of low-income households in two developing countries. Transport Research Laboratory (TRL) 263, UK

12. Pedersen, P.O. (2000) The changing structure of transport under trade liberalization and globalization and its impact on African development Centre for Development Research (Denmark) Copenhagen : CDR working papers; 00.1. Working paper subseries on globalisation and economic restructuring in Africa no. vii

13. Sohail, M. (Ed.) (2003 A) Partnership to improve access and quality of public transport A case report: Faisalabad, Pakistan, WEDC: Loughborough University, ISBN: 184380038 1, 236 PP.

14. Sohail, M. (Ed.) (2003 B) Partnership to improve access and quality of public transport A case report: Colombo, Sri-Lanka, WEDC: Loughborough University, ISBN: 184380036 5, 94 PP. 
15. Sohail, M. (Ed.) (2003 C) Partnership to improve access and quality of public transport A case report: Dar-es-Salam, Tanzania, WEDC: Loughborough University, ISBN: 184380037 3, 116 PP.

16. Sohail, M. (Ed.) (2000) Urban Public Transport and Sustainable livelihoods for the poor: A case study in Karachi, Paksitan. WEDC: Loughborough University, UK.

17. Sohail, M., Mitlin, D. and Maunder, D.A.C (2003) Guidelines Partnership to improve access and quality of public transport, WEDC: Loughborough University, 2003, ISBN: 184380035 7, 130 PP.

18. World Bank (1994) World Development Report 1994: Infrastructure for Development, World Development Indicators. The World Bank: Washington D.C.

19. World Bank (1986) Urban Transport: A World Bank policy study. World Bank: Washington D.C.

20. Urban Resource Centre (2001) Urban poverty and transport: a case study from Karachi Environment and urbanization, 13, no.1, 223-233

21. Vasconcellos, E. A. (2001) Urban transport, environment and equity: the case for developing countries London: Earthscan.

22. Yin, R.K. (1993) Applications of Case Study Research. Sage Publications: Thousand Oaks, USA.

23. United Nations (2001), World Urbanization Prospects: the 1999 Revision, United Nations (Population Division), New York

24. NTC (1989) A Review of Urban Public Transport in Dar Es Salaam 1965-1982.

25. W/S Atkins International UK Colombo Urban Transport Study - stage 2

26. Census of Colombo Population (2001)

27. Urban Development Authority (1996) City of Colombo Development Plan.

28. CIA The World Fact Book 
Table 6: Comparison of Findings between the Case Study Locations.

\begin{tabular}{|c|c|c|c|}
\hline & Faisalabad & Colombo & Dar es Salaam \\
\hline Background & $\begin{array}{l}\text { Public transport availability has not } \\
\text { grown at the same rate as the } \\
\text { workforce. Those living in } \\
\text { unplanned settlements or live } \\
\text { illegally as squatters/slums. }\end{array}$ & $\begin{array}{l}\text { After two decades of } \\
\text { nationalisation, in 1979, the } \\
\text { government decided to permit } \\
\text { private bus owners to operate } \\
\text { regular services on all routes to } \\
\text { complement/compete with public } \\
\text { sector buses. }\end{array}$ & $\begin{array}{l}\text { City is highly concentrated with rapid } \\
\text { population growth since the late } \\
\text { 1940s. Historically public transport } \\
\text { was a government monopoly until } \\
1983 \text {. }\end{array}$ \\
\hline $\begin{array}{l}\text { Modes of } \\
\text { public } \\
\text { transport }\end{array}$ & $\begin{array}{l}\text { Tongas (animal drawn vehicle), } \\
\text { conventional rickshaws, motorcycle } \\
\text { rickshaws, buses, wagons, and taxis. } \\
\text { The market is dominated by Suzuki } \\
\text { pick ups. }\end{array}$ & $\begin{array}{l}\text { Pedal cycles, motor cars, motor } \\
\text { cycles, school vans and office staff } \\
\text { transport, three wheelers, private } \\
\text { bus transport, rail transport, public } \\
\text { buses. }\end{array}$ & $\begin{array}{l}\text { Public transport is now provided by } \\
\text { daladala buses medium sized Toyota- } \\
\text { DCM, Isuzu and Toyota Coaster } \\
\text { buses, or buses which carry between } \\
20-22 \text { people. }\end{array}$ \\
\hline $\begin{array}{l}\text { Problems and } \\
\text { illegalities in } \\
\text { formal and } \\
\text { informal } \\
\text { transport } \\
\text { sectors }\end{array}$ & $\begin{array}{l}\text { - } \text { Overcrowding } \\
\text { Ban on smoking on } \\
\text { public transport is not } \\
\text { enforced. } \\
\text { - } \quad \text { Few proper bus stops. } \\
\text { The poor condition of } \\
\text { roads and pavements. } \\
\text { Poor interior conditions } \\
\text { of public transport. } \\
\text { Bad behaviour of } \\
\text { operators } \\
\text { passengers. } \\
\text { Poor safety of children } \\
\text { when travelling. } \\
\text { - Loud music played by } \\
\text { bus operators, } \\
\text { Limited pedestrian } \\
\text { crossings, signs for road } \\
\text { safety. } \\
\text { - City buses, wagons and } \\
\text { pickups are } \\
\text { overcrowded inside and } \\
\text { on the roof during peak } \\
\text { hours. } \\
\text { Manner in which } \\
\text { passengers are picked } \\
\text { op and dropped off. } \\
\text { of public transport. }\end{array}$ & 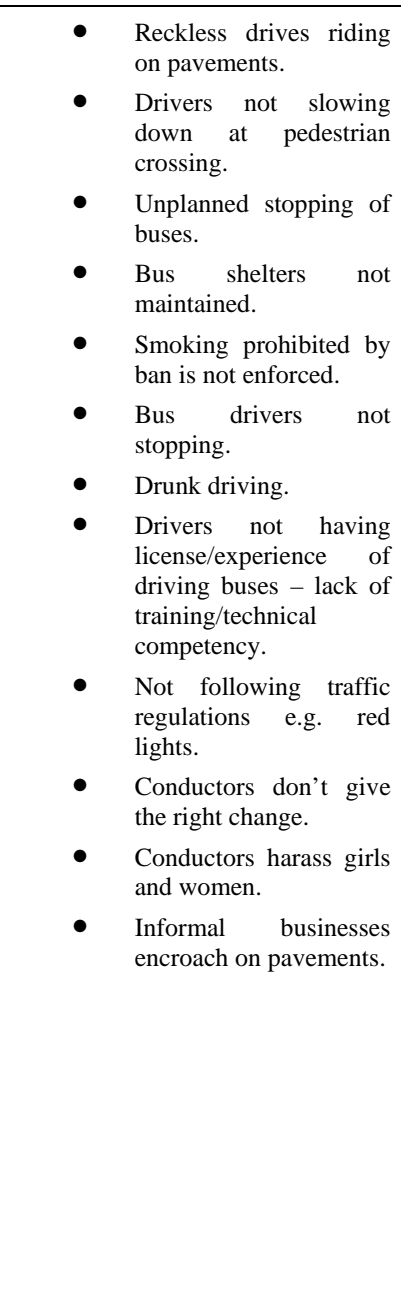 & 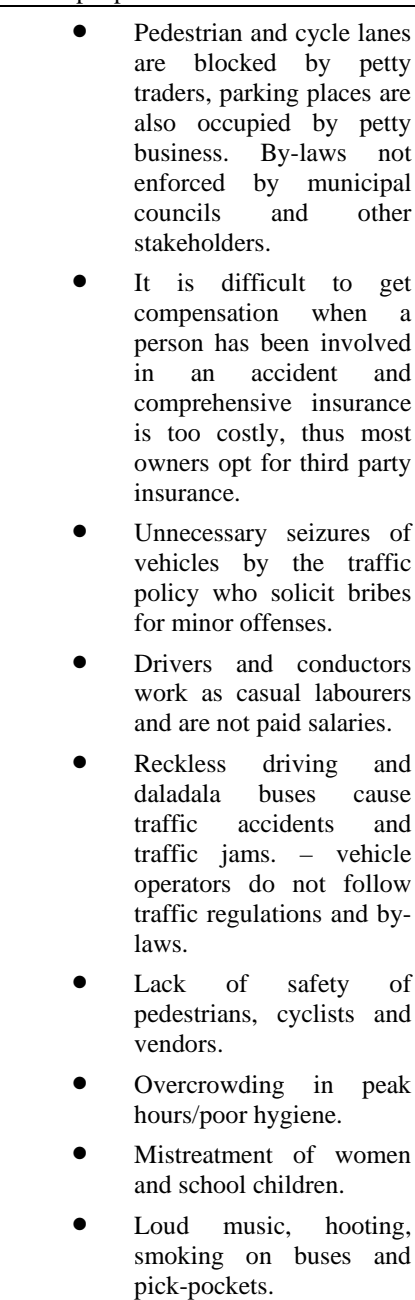 \\
\hline $\begin{array}{l}\text { Public } \\
\text { transport and } \\
\text { the poor }\end{array}$ & $\begin{array}{l}\text { There is a disparity of } \\
\text { service between } \\
\text { different parts of city. } \\
\text { Uneconomic for private } \\
\text { operators to service } \\
\text { routes on city outskirts } \\
\text { off-peak. }\end{array}$ & $\begin{array}{l}\text { Public bus fares are affordable } \\
\text { because the fare is controlled by the } \\
\text { Ministry of Transport but there are } \\
\text { general complaints with pedestrian } \\
\text { travel, frequency and time of } \\
\text { operation of public transport, } \\
\text { condition of transport modes, } \\
\text { service crew and their performance. }\end{array}$ & $\begin{array}{l}\text { Current fare charges for buses are } \\
\text { seen as too high, with many } \\
\text { complaints abut the quality of service. } \\
\text { Poor people affected by the fact that } \\
\text { private operators were not willing to } \\
\text { service areas that had poor roads }\end{array}$ \\
\hline $\begin{array}{l}\text { Passengers } \\
\text { perspectives }\end{array}$ & 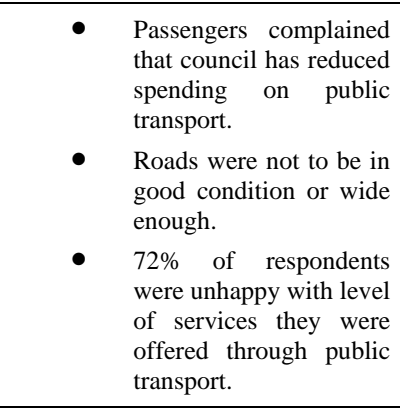 & $\begin{array}{l}\text { - Buses stops should be } \\
\text { properly planned and } \\
\text { bus shelters with seating } \\
\text { facilities should be } \\
\text { constructed. } \\
\text { - There is a need for } \\
\text { wider pavements, free } \\
\text { of obstructions. } \\
\text { - Pedestrian crossings } \\
\text { must be provided at } \\
\text { convenient places. } \\
\text { - Education should take }\end{array}$ & 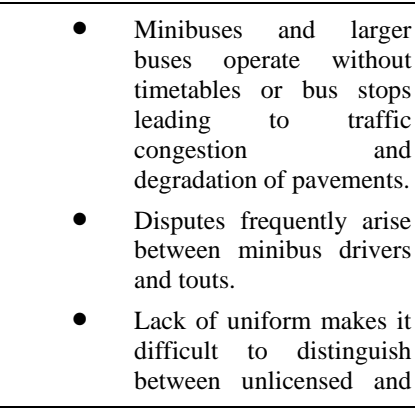 \\
\hline
\end{tabular}




\begin{tabular}{|c|c|c|c|}
\hline & $\begin{array}{l}\text { Complaints of dirty } \\
\text { clothing after trips on } \\
\text { buses or wagons. } \\
63 \% \text { thought transport } \\
\text { was dangerous. } \\
90 \% \text { thought overall } \\
\text { standard was bad for } \\
\text { passenger health. } \\
\text { The cost of transport is } \\
\text { a high proportion of } \\
\text { user incomes. }\end{array}$ & $\begin{array}{l}\text { placed on traffic rules \& } \\
\text { regulations. } \\
\text { Load limits should be } \\
\text { introduced on buses. } \\
\text { Interior of buses should } \\
\text { be re-designed (seats, } \\
\text { handrails, bells and } \\
\text { steps) to meet needs of } \\
\text { disabled. }\end{array}$ & $\begin{array}{l}\text { licensed drivers. } \\
\text { Conductors were reported } \\
\text { to use abusive language to } \\
\text { women and girls that do } \\
\text { not get off the bus quickly } \\
\text { enough. } \\
\text { Buses were said to be } \\
\text { unhygienic, particularly } \\
\text { on hot days, leading to } \\
\text { soiling and wrinkling } \\
\text { passengers clothes. }\end{array}$ \\
\hline $\begin{array}{l}\text { Vehicle } \\
\text { owners } \\
\text { perspectives }\end{array}$ & $\begin{array}{l}\text { - } 76 \% \text { of employees were } \\
\text { illiterate. } \\
\text { - Few crew members } \\
\text { understood the } \\
\text { mechanism of the } \\
\text { vehicles they were } \\
\text { driving/conducting. } \\
\text { Management controls } \\
\text { were minimal. } \\
\text { Drivers were trusted to } \\
\text { return daily incomes to } \\
\text { owners. }\end{array}$ & $\begin{array}{l}\text { Government should co- } \\
\text { ordinate private bus } \\
\text { operations \& ensure that } \\
\text { private operators earn } \\
\text { sufficient income. } \\
\text { - } \quad \text { Public transport related } \\
\text { infrastructure should } \\
\text { ensure that services can } \\
\text { operate smoothly. } \\
\text { The route allocation } \\
\text { system must prevent } \\
\text { oversupply of buses. } \\
\text { Need for concessionary } \\
\text { loan repayments/fuel } \\
\text { subsidies. }\end{array}$ & $\begin{array}{l}\text { - Demands for tax relief on } \\
\text { the running costs (spare } \\
\text { parts and fuel) paid by } \\
\text { owners of daladala. } \\
\text { Owners would like bus } \\
\text { fares raised to cover } \\
\text { operational costs. } \\
\text { - Improvements } \\
\text { infrastructure of roads and } \\
\text { terminals - shelters, } \\
\text { benches, public toilets, } \\
\text { drains, bus stops, parking } \\
\text { bays. } \\
\text { Uniforms should be worn } \\
\text { by drivers and conductors. } \\
\text { The Dar es Salaam } \\
\text { Regional Transport } \\
\text { Licensing Authority } \\
\text { should be more } \\
\text { transparent on the } \\
\text { allocation of bus routes. } \\
\text { They suggested the need } \\
\text { to establish a course on } \\
\text { public transport issues. }\end{array}$ \\
\hline $\begin{array}{l}\text { Bus drivers } \\
\text { and } \\
\text { conductors } \\
\text { perspectives }\end{array}$ & 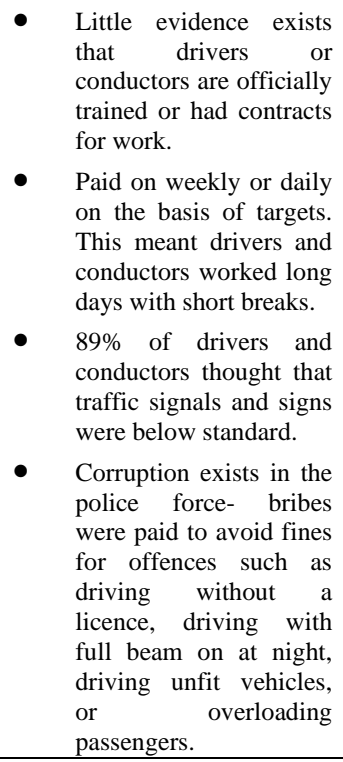 & $\begin{array}{l}\text { Employment status of } \\
\text { private bus conductors } \\
\text { and drivers must be } \\
\text { changed with training, } \\
\text { recognition and } \\
\text { contracts. } \\
\text { Working conditions of } \\
\text { crews must be changed. } \\
\text { - Awareness raising of } \\
\text { passengers of road } \\
\text { safety. }\end{array}$ & $\begin{array}{l}\text { Drivers and conductors } \\
\text { have targets to meet. They } \\
\text { work long days with little } \\
\text { break. } \\
\text { Drivers and conductors } \\
\text { lack of formal } \\
\text { employment contracts } \\
\text { with bus owners. } \\
\text { They stated a need for an } \\
\text { association to safeguard } \\
\text { employment and working } \\
\text { hours. } \\
\text { They reported corruption } \\
\text { in traffic police. } \\
\text { They requested more } \\
\text { durable and comfortable } \\
\text { uniforms. }\end{array}$ \\
\hline Regulation & $\begin{array}{l}\text { - The Regional Transport } \\
\text { Authorities has power to } \\
\text { issue routes to all } \\
\text { motorised vehicles, } \\
\text { vehicle body } \\
\text { manufacturing licences, } \\
\text { check overloading, issue } \\
\text { licences to goods } \\
\text { forwarding agencies and } \\
\text { impose penalties on } \\
\text { violators. } \\
\text { The office of the Motor } \\
\text { Vehicle Examiner } \\
\text { issues and renews } \\
\text { roadworthiness }\end{array}$ & $\begin{array}{l}\text { A number of agencies do } \\
\text { exist in Sri Lanka to } \\
\text { guide and regulate public } \\
\text { transport services. } \\
\text { however due to a lack of } \\
\text { proper coordination at } \\
\text { national as well as city } \\
\text { level. } \\
\text { Regulatory agency } \\
\text { personnel emphasize the } \\
\text { need for all parties to } \\
\text { cooperate in } \\
\text { implementing traffic rules } \\
\text { and regulations. } \\
\text { It has been observed that } \\
\text { there are no significant }\end{array}$ & $\begin{array}{l}\text { Traffic Department of the } \\
\text { police force is responsible } \\
\text { for designating and } \\
\text { allocating routes to public } \\
\text { bus operators, the Dar es } \\
\text { Salaam Regional } \\
\text { Transport Licensing } \\
\text { Authority (DRTLA) is } \\
\text { responsible for } \\
\text { monitoring and enforcing } \\
\text { route compliance among } \\
\text { operators. is } \\
\text { The police forces is } \\
\text { involving in inspecting } \\
\text { vehicles for their }\end{array}$ \\
\hline
\end{tabular}




\begin{tabular}{|c|c|c|c|}
\hline & $\begin{array}{l}\text { certificates for } \\
\text { motorised public } \\
\text { transport and impose } \\
\text { penalties on violators. } \\
\text { - } \text { The Traffic Police } \\
\text { Department is } \\
\text { responsible for issuing } \\
\text { Heavy/ Light Transport } \\
\text { Vehicles licenses, } \\
\text { implementing traffic } \\
\text { laws, controlling the } \\
\text { flow of traffic, checking } \\
\text { vehicle ownership and } \\
\text { watching for violators. } \\
\text { The Tax Brach are } \\
\text { responsible for issuing } \\
\text { licenses/permits and } \\
\text { enforcing bylaws for } \\
\text { animal drawn vehicles } \\
\text { and imposing penalties } \\
\text { on violators. }\end{array}$ & $\begin{array}{l}\text { partnership arrangements } \\
\text { in operation in this sector. } \\
\text { Other transport modes } \\
\text { such as school vans, } \\
\text { three-wheelers and office } \\
\text { staff transport vans, are } \\
\text { operated mostly on an } \\
\text { individual basis with no } \\
\text { effective partnership } \\
\text { arrangement between } \\
\text { users, transport operators } \\
\text { and regulators. } \\
\text { As well as roads, } \\
\text { infrastructure such as } \\
\text { pavements or cycle lanes } \\
\text { are needed to make } \\
\text { walking to work or school } \\
\text { safe and accessible. } \\
\text { Traffic management } \\
\text { measures such as one- } \\
\text { way streets, removal of } \\
\text { encroachments and better } \\
\text { signalling would help. }\end{array}$ & $\begin{array}{l}\text { roadworthiness } \\
\text { testing of drivers for } \\
\text { professional competency } \\
\text { in driving. } \\
\text { There is no clearly } \\
\text { defined urban public } \\
\text { transport policy. }\end{array}$ \\
\hline Issues & $\begin{array}{l}\text { - Income inequality is } \\
\text { high in Faisalabad, } \\
\text { which causes problems } \\
\text { for the pricing of public } \\
\text { transport. } \\
\text { - Inadequate } \\
\text { infrastructure is a basic } \\
\text { problem. } \\
\text { Many poor areas are not } \\
\text { directly linked to main } \\
\text { roads. } \\
\text { Traffic management } \\
\text { measures such as one } \\
\text { way streets, removal of } \\
\text { encroachments and } \\
\text { better signalling are } \\
\text { needed. } \\
\text { There is a need to } \\
\text { development } \\
\text { enforcement technology } \\
\text { systems. }\end{array}$ & 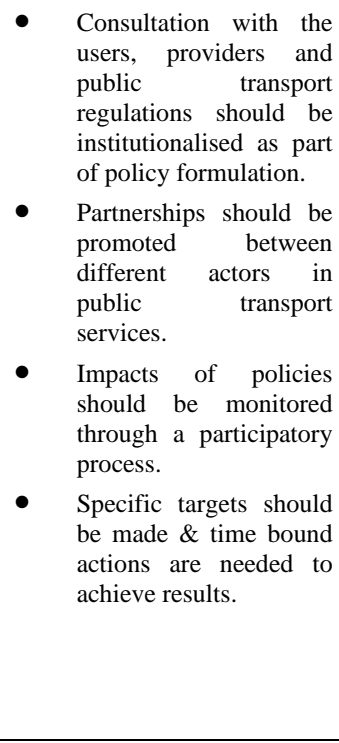 & $\begin{array}{l}\text { - Road transport network is } \\
\text { poor and does not } \\
\text { encourage use of non } \\
\text { motorised transport in } \\
\text { parts of the city. } \\
\text { - The fragmented provision } \\
\text { of public transport makes } \\
\text { it difficult to prepare } \\
\text { focused plans and } \\
\text { effective traffic } \\
\text { management. } \\
\text { Public transport for school } \\
\text { children needs special } \\
\text { attention. } \\
\text { There is a need for } \\
\text { alternative means of } \\
\text { goods transport. } \\
\text { There is an urgent need to } \\
\text { establish a forum for } \\
\text { discussion whereby bus } \\
\text { owners, operators and } \\
\text { users would meet to } \\
\text { discuss public transport. }\end{array}$ \\
\hline
\end{tabular}




\section{Appendix 1.Methodological considerations}

The following are some of the considerations for the design of the research which were proposed in the Inception report and were pursued during the research.

The assumption of this research project is that transport services make a significant contribution to the livelihood strategies of the urban poor. Transport services' contributions (both positive and negative) to livelihoods includes access to employment and income generation opportunities, education, health, and social networks such as extended families, which can help in securing incomes and necessary goods and services. Variables that affect use include the cost and accessibility of transport services, reliability, safety getting onto and off the vehicles, along with levels of comfort during the journey, and location and quality of pick-up and drop-off points. Transport services have a further potential impact on environmental and health aspects of life in low-income settlements through noise, air pollution and traffic accidents.

With this understanding, this research project sought to:

- investigate existing community-based, commercial, NGO and institutional roles and responsibilities for the provision of transport services in urban poor communities in case locations and, in so doing, better understand the impact of such services on the well-being of the urban poor;

- identify improvements that can be undertaken;

- establish a process that develops a momentum for the implementation of these improvements; and

- develop a framework for use elsewhere in order to improve transport services for the urban poor.

The research project sought primarily to understand the differentiated perspectives of the urban poor with respect to transport. In order to identify service improvements, it also sought a better understanding of the perspectives of providers of transport services. The research process was designed to bring together these perspectives in order to increase the possibility of securing such improvements.

The following methods were used for the collection of information during the research process.

- A literature review and synthesis of secondary data;

- Case studies in specific communities. Information was gathered through semistructured interviews with key informants in four to five low-income settlements as well as public, private and civil society representatives. Focus group discussions with different ages, ethnic and gender groups within each settlement were used to follow up on issues identified through the individual interviews. Focus group discussions were also held with the private sector providers(primarily rickshaws, taxis, buses and mini-buses and trade associations). 
- Findings were presented to a wide group of leaders from urban poor communities through City Forums. The forums provide the means by which stakeholders can become involved in the research process.

The analysis of data was undertaken in the following ways:

- Information from the semi-structured interviews was compared across the case study communities, with similarities and discrepancies being highlighted. Comparative analysis (pattern matching) was undertaken by the user group and by the transport group. Differences between user groups, transport groups and settlements were identified and further explored through the city forums.

- Numeric information (for example, on the numbers of journeys, cost of journeys, reasons for journeys) was tabulated where possible.

- The analysis of information from the interviews was summarized prior to the focus group discussions. The focus group discussions within the low-income settlements were structured to allow for comparative analysis.

Verification was achieved primarily through triangulation with the following four sources of data cross-checked to ensure reliability:

- individual interviews;

- discussions with communities and stakeholder groups;

- existing data on transport and the urban poor; and

- interviews with key informants.

It is believed that the most significant strengths of the chosen methodology are that it:

- produced a rich understanding of local perspectives, differentiated by groups within the urban poor;

- engaged key groups in the research process;

- provided a new source of information for stakeholder groups to consider; and

- enabled recommendations for improvements to emerge from, and be considered within, the research process.

Care was taken to ensure:

- 'generalisability' and representativeness of settlements/sample chosen

- involvement of key stakeholders

- a comprehensive and detailed understanding of the transport-related problems faced by the urban poor 